\title{
Menjanda sebagai Model Resiliensi Perempuan
}

\author{
Hoiril Sabariman, ${ }^{1 *}$ Siti Kholifah ${ }^{2}$ \\ ${ }_{1}^{1}$ Program Studi Magister ilmu-ilmu Sosial, Fakultas Ilmu Sosial dan Ilmu Politik, \\ Universitas Brawijaya, ${ }^{2}$ Departemen Sosiologi, Fakultas Ilmu Sosial dan Ilmu Politik \\ Universitas Brawijaya, Malang - Indonesia
}

\begin{abstract}
Women in rural Madura prefer to live alone as a widow after being left by husbands (divorced/deceased). This phenomenon is better known as a single mother. The single mother women perform dual roles in the family, namely public roles and domestic roles. This research focuses on the causes of women who prefer to be single mothers as well as their strategies in maintaining resilience in the family. The case study approach and qualitative methods are used to understand the phenomenon. The data show that several factors influence women in Ponteh village to live longer as single mothers than men after getting divorced. Firstly, wanting to raise their children, secondly, for women, divorce is a traumatic event, third, understanding of Islamic thought, fourth, social prestige. The resilience of single mothers is indicated by their multiple roles as women. Women are more active in productive activities as well as reproductive or domestic activities. The contribution of this article is to explain more about the single mother phenomenon in rural Madura.

Perempuan di perdesaan Madura lebih memilih hidup sendiri (menjanda) setelah ditinggal suami (cerai/ meninggal). Fenomena ini lebih dikenal dengan single mother. Perempuan single mother menjalankan peran ganda dalam keluarga, yaitu peran publik dan peran domestik. Penelitian ini fokus pada penyebab perempuan lebih memilih menjadi single mother serta strategi menjalani resiliensi dalam keluarga. Pendekatan studi kasus dengan metode kualitatif digunakan untuk memahami fenomena tersebut. Data menunjukkan, terdapat beberapa faktor perempuan di Desa Ponteh lebih lama untuk tidak menikah setelah bercerai daripada laki-laki. Pertama, ingin membesarkan anak sendiri. Kedua, bagi perempuan yang bercerai masih trauma. Ketiga, pemahaman ajaran agama Islam. Keempat, gengsi. Resiliensi yang dilakukan perempuan single mother secara garis besar adalah dengan menjalankan peran ganda. Perempuan lebih aktif dalam kegiatan produktif, tetapi tidak melupakan peran domestik dalam rumah tangga. Kontribusi keilmuan artikel ini adalah, menjelaskan lebih lanjut tentang fenomena perempuan single mother di perdesaan Madura.
\end{abstract}

Keywords: single mother; resiliency; women; Madura

*Korespondensi Penulis: Hoiril Sabariman (hoirilsabariman@yahoo.com), mahasiswa Program Studi Magister ilmu Sosial, Fakultas Ilmu Sosial dan Ilmu Politik, Universitas Brawijaya, Jl. Veteran Malang, Kota Malang, Jawa Timur 65145. 


\section{Pendahuluan}

Fenomena "single mother" atau perempuan yang bertahan untuk tetap menjanda merupakan fenomena di kalangan komunitas perempuan yang tidak dapat diabaikan. Fenomena perempuan menjanda menarik untuk dikaji karena ada dua nilai budaya yang harus dihadapi oleh perempuan. Pertama, peran gender yang melekat pada perempuan ketika sebagai istri menjadikan perempuan memiliki peran domestik (Edin 2000). Ketika perempuan memutuskan untuk menjanda maka problem produktif harus dihadapi (Cairney et al. 2003). Perempuan harus "keluar rumah" untuk memenuhi peran produktifnya. Kedua imaje "janda" dalam masyarakat merupakan imaje yang berat untuk ditanggung perempuan. Banyak stereotype yang dikembangkan oleh masyarakat berkait dengan perempuan yang "tidak memiliki suami" ini. Tak pelak stereotype janda sebagai "pengganggu dan perebut suami orang" dalam konteks nilai masyarakat merupakan stereotype yang membuat perempuan enggan untuk menjanda. Dalam konteks nilai kemasyarakatan dan budaya seperti ini, kajian ini menarik untuk dilakukan.

Single mother merupakan perempuan yang memilih hidup sendiri dalam menjalani peran dalam keluarga tanpa didampingi oleh suami. Single mother disebabkan oleh kematian pasangan hidup, perceraian, terpisah tempat tinggal dengan pasangan (Edin 2000; Solikhah 2016; Wahyuni, Soemanto, dan Haryono 2015). Meskipun perempuan menjadi single mother, setidaknya beberapa fungsi dasar keluarga harus terpenuhi. Beberapa fungsi dasar keluarga; pertama, fungsi produksi, mempertahankan dan menjaga kondisi masyarakat agar berkembang dan membentuk struktur yang baik. Kedua, fungsi sosialisasi, sebagai tempat melanjutkan nilai-nilai, keyakinan, pengetahuan, sikap, keterampilan. Ketiga, fungsi peran sosial dalam masyarakat, memberikan identitas baik tentang politik, ekonomi, religi, etnik dan peran gender. Keempat, fungsi dukungan ekonomi, disediakan jaminan sosial dalam melanjutkan kehidupan, seperti makanan dan tempat berlindung. Kelima, fungsi dukungan emosi, memberikan pelajaran dan bimbingan ketika berinteraksi dengan lingkungan masyarakat. Interaksi yang diajarkan bersifat lebih mendalam serta berkelanjutan (Lestari dalam Saprin 2015).

Perempuan yang menjadi single mother memerlukan jiwa kemandirian untuk menjalankan dua peran sekaligus, yaitu peran domestik seperti merawat, membesarkan dan mendidik anak, membersihkan rumah, mencuci piring dan pakaian, memasak, menyiapkan makanan untuk keluarga dan peran publik (fungsi produksi) (Layliyah 2013; Matondang 2014).

Perempuan sudah masuk dalam ranah publik yang lazim ditempati oleh laki-laki (Adela et al. 2019; Arini 2014; Ramadhani 2015). Masuknya perempuan dalam wilayah publik disebabkan oleh beberapa faktor, antara lain, keinginan perempuan untuk mendapat penghasilan, keinginan perempuan sendiri untuk berkembang, seiring dengan tingkat pendidikan, kapasitas dan kapabilitas perempuan, tuntutan zaman yang memang memaksa perempuan untuk mengikuti perkembangan, dan meningkatkan eksistensi perempuan itu sendiri, baik dalam keluarga dan masyarakat (Hidayati 2015). Kondisi perempuan bekerja dengan menjalani dua fungsi sekaligus salah satunya adalah fenomena single mother.

Peran publik untuk mencari nafkah keluarga, secara sosial seorang single mother harus dapat berkomuniasi dan bersosialisasi dengan komu- 
nitas perempuan tempat itu tinggal. Seorang single mother, dapat mencapai keseimbangan antara peran domestik dan peran publik dengan usaha kesabaran, pengetahuan dan konsistensi dalam menjalankan peran ganda tersebut.

Sebagai single mother untuk berkerja mencari nafkah, terdapat banyak pertimbangan dari sumber penghasilan, efisiensi waktu untuk menjalankan tugas utama sebagai seorang ibu tanpa mengesampingkan pekerjaan rumah tangga. Oleh karena itu, sebagai single mother perempuan dituntut untuk dapat beradaptasi dan melanjutkan hidup tanpa suami, mencari nafkah dan menyeimbangkan antara peran domestik dan publik (Rahayu 2017).

Perkembangan literatur yang membahas fenomena perempuan yang menjadi single mother dan resiliensi di Indonesia setidaknya dijelaskan oleh Bianca (2014), Nurpuspita (2018). Menurut Bianca (2014) single mother dipilih oleh perempuan yang ditinggal suami meninggal dunia memilih untuk tidak menikah karena trauma. Sehingga lebih menerima untuk menjadi single mother dalam melanjutkan peran ganda dalam keluarga. Sedangkan menurut Nurpuspita (2018) perempuan memilih untuk tidak cepat menikah ketika ditinggal pasangan hidup karena mempunyai prioritas utama saat ini yaitu untuk kebaikan anak. Hal ini menjadi pertimbangan utama untuk membesarkan anak, sehingga kelak berharap anak-anaknya dapat tumbuh mandiri, tidak tergantung kepada orang lain. meskipun rencana menikah tetap ada, namun untuk saat ini prioritas membesarkan anak menjadi yang utama.

Alasan perempuan menjadi single mother serta resiliensi pada setiap individu memiliki bentuk yang berbeda-beda. Tidak sedikit per- empuan yang memilih untuk menjadi single mother karena sudah merasa cukup dan mampu untuk mendirikan suatu keluarga walaupun tanpa didampingi oleh pasangan (Hude 2001:33).

Mawardi, Ma'sumah, dan Zulizar (2017) mennyatakan bahwa menjadi seorang single mother merupakan pilihan. Bentuk resiliensi yang dilakukan oleh perempuan di Kabupaten Cilacap adalah berhutang kepada orang lain untuk memenuhi kebutuhan, terutama kebutuhan yang sifatnya mendesak. Hal ini dilakukan karena perempuan tidak memiliki pekerjaan tetap. Ketergantungan perempuan pada bantuan orang lain begitu tinggi, baik kepada tetangga, saudara, teman, juragan tempat bekerja, bahkan anak yang sudah dewasa dan bekerja. Pada kondisi yang serba kekurangan ini, langkah yang dilakukan adalah hidup dengan sederhana, menerapkan sistem gali lubang tutup lubang untuk menjalani kehidupan.

Sedangkan menurut Paramitha dan Susilawati (2016) perempuan janda nyerod (karena bercerai) yang pernah mulih deha (pulang ke kampung orang tua) melakukan resiliensi yang terdiri dari delapan tahap yaitu, adverse event (nyerod), succumbing, survival, adverse event (kehilangan pasangan hidup), succumbing, survival, recovery dan thriving. Perempuan janda nyerod yang pernah mulih deha perlu dukungan internal dan eksternal. Dukungan internal berasal dari diri perempuan tersebut. Perempuan memiliki harapan dan motivasi untuk dapat keluar dari masamasa sulit. Sedangkan faktor eksternal adalah faktor anak, keluarga dan lingkungan masyarakat. Penjelasan berbeda dipaparkan oleh Rahayu (2017) tentang strategi sosial yang dilakukan perempuan single mother, pertama hidup bersama orang tua. Hal ini dilakukan untuk menghindari tekanan sosial dalam masyarakat. Selain 
itu, saat perempuan bekerja anak dapat dititipkan kepada orang tua. Meskipun perempuan sibuk mencari nafkah, perawatan, pendidikan anak tetap berlangsung. Kedua, strategi adaptasi ekonomi bagi perempuan yang menjadi single mother adalah menyelaraskan antara jumlah pendapatan dan kebutuhan sehari-hari. Kemudian menabung, sambil menyisihkan dari pendapatan untuk kebutuhan mendadak dan persiapan pendidikan anak di kemudian hari (Pandapotan dan Andayani 2018).

Hasanah dan Retnowati (2019) menjelaskan proses awal dari perempuan yang memilih menjadi single mother dalam dinamika resiliensi seperti disfungsi keluarga yang diakibatkan oleh perbedaan peran yang diemban sebelumnya, masalah finansial yang tidak menentu karena ditinggal pasangan, masalah sosial yang diakibatkan oleh perspektif masyarakat tentang perempuan single mother, stres pengasuhan anak pada ibu, serta yang terakhir adalah keyakinan terhadap hal-hal mistis. Permasalahan hidup yang dialami menimbulkan berbagai dampak negatif pada kondisi fisik maupun psikologis. Problem focused coping dan emotional focus coping, digunakan untuk mengatasi berbagai permasalahan yang ditimbulkan akibat permasalahan tersebut, serta memperoleh dukungan dari lingkungan. Proses bangkit dan penguatan resiliensi pada ibu single parent dengan anak tuna ganda didukung adanya faktor protektif seperti memiliki harapan, belajar dari pengalaman, kelekatan yang terjalin antara anak dan ibu, dan keyakinan religius. Percaya bahwa Tuhan menitipkan sesuatu sesuai dengan kemampuan dari tiaptiap individu (Hasanah dan Retnowati 2019). Untuk mengurangi tingkat stress pada perempu- an single mother perlu dukungan sosial masyarakat sekitar (Cairney et al. 2003).

Selanjutnya, kajian Miftahurrohmah (2015) yang lebih fokus pada menajemen yang dilakukan oleh perempuan single parent dalam kehidupan keluarga. Manajemen dilakukan oleh perempuan single parent dengan memilih dan memilah kebutuhan dengan mementingkan pemenuhan kebutuhan sandang, pangan dan papan dengan cara sederhana. Sedangkan pemenuhan kebutuhan aktualisasi diri, pendidikan, keagamaan, sosial, budaya dilakukan dengan ikut aktif dalam berbagai kegiatan dilingkungan tempat tinggal perempuan yang menjadi single parent, misal Muslimat, jami'iyyah pegajian dan Fatayat.

Perempuan di Desa Ponteh Kecamatan Galis Kabupaten Pamekasan banyak yang memilih hidup sendiri dengan fungsi peran ganda dalam keluarga, baik dalam ranah domestik maupun dalam ranah publik. Hal ini dikarenakan sebagian besar perempuan yang menjadi single mother berasal dari keluarga kurang mampu, selain itu para perempuan tidak memiliki penghasilan tetap. Perempuan di Desa Ponteh lebih lama sendiri dan mengurus anak, daripada laki-laki yang lebih cepat membina rumah tangga kembali setelah cerai/meninggal dari pasangannya (Profil Desa, 2018). Perempuan yang menjalani peran sebagai single mother bukan merupakan sesuatu hal yang mudah, sebab dalam keseharian perempuan tidak hanya bekerja di sektor publik menggantikan peran suami sebagai kepala keluarga yang bertugas mencari nafkah, tetapi juga bekerja dalam ranah domestik sebagai ibu rumah tangga dan mendidik anak-anak.

Berbeda dengan artikel-artikel sebelumnya yang sudah diulas (Hasanah dan Retnowati 2019; 
Mawardi et al. 2017; Miftahurrohmah 2015; Paramitha dan Susilawati 2016; Rahayu 2017), artikel ini selain menjelaskan faktor-faktor perempuan menjadi single mother serta resiliensi di Desa Ponteh Kecamatan Galis Kabupaten Pamekasan yang sangat beragam. dengan kompleksitas permasalahan yang dihadapi oleh perempuan single mother dalam keluarga. Artkel ini juga menjelaskan faktor-faktor penyebab perempuan lebih lama untuk membina keluarga kembali setelah suami meninggal atau cerai dan memilih hidup sendiri dibandingkan dengan lakilaki yang cerai atau karena istri meninggal. Faktorfaktor ini meliputi faktor anak, psikologis, agama, dan kebutuhan eksistensial. Lebih lanjut, artikel ini juga menjelaskan resiliensi perempuan single mother dalam menghadapi kebutuhan keluarga dan sosial dalam masyarakat.

Penelitian ini menggunakan pendekatan studi kasus untuk menjelaskan secara komprehensif tentang perempuan single mother dalam keseharian, dunia intersubyektif (dunia kehidupan). Data yang digunakan dari penelitian ini data primer, diperoleh dari hasil wawancara mendalam, observasi yang dilakukan pada perempuan single mother di Desa Ponteh Kecamatan Galis Kabupaten Pamekasan sebagai objek penelitian. empat perempuan sebagai Informan penelitian ini ditentukan berdasarkan pertimbangan dan kriteria tertentu. pertama; perempuan yang bercerai/ditinggal suami dan menanggung anak. Kedua; perempuan dari kalangan ekonomi menengah ke bawah (Creswell dan Creswell 2017).

Penelitian ini bertujuan untuk melihat perempuan yang memilih untuk hidup sendiri dan membesarkan anak dengan beban ganda dalam keluarga. Selain sebagai ibu rumah tangga, perempuan single mother juga sebagai kepala rumah tangga dan mencari nafkah untuk keluarga. Serta resiliensi perempuan dalam menghadapi tuntutan sosial, ekonomi, politik dalam keluarga atau lingkungan masyarakat di Desa Ponteh.

Pengumpulan data dalam penelitian ini dilakukan dengan cara observasi dan wawancara mendalam. Wawancara telah dilakukan kepada Ibu Munami, seorang perempuan dua anak yang ditinggal cerai suami. Ibu Ika, seorang perempuan yang ditinggal suami (seorang kiai) karena meninggal. Ibu Rahma, seorang perempuan satu anak yang ditinggal suami karena bercerai. Dalam keseharian Ibu Lia bekerja sebagai buruh tani di Desa Ponteh. Pengumpulan data dengan cara seperti ini telah memberikan pemaparan secara mendalam tentang fenomena perempuan single mother, serta kejelasan informasi yang didapat dan lebih luas cakupan terhadap fenomena diteliti. Wawancara terhadap informan penelitian dilakukan dengan menggunakan panduan wawancara yang dibuat sebelumnya, sesuai dengan fokus penelitian. Tetapi panduan tidak menjadi dasar dari setiap pertanyaan, hanya sebagai kontrol. Karena pertanyaan lebih mengikuti pada pemahaman dan kondisi informan saat proses wawancara. Hasil observasi, wawancara yang telah diperoleh kemudian diringkas dan dibandingkan. Ketika terdapat pertanyaan yang sama dan jawaban berbeda diidentifikasi kemudian dikoreksi. Selain dari observasi dan wawancara, data juga dikumpulkan dari berbagai publikasi yang sesuai dengan fokus penelitian.

Setelah data terkumpul, baik data primer dan data sekunder, langkah berikutnya adalah analisis data. Metode analisis data yang digunakan adalah model interaktif Miles dan Huberman (Miles, Huberman, dan Saldana 2014). Metode analisis ini dimulai dengan mengumpulkan data di lokasi 
penelitian, baik observasi atau wawancara. Kemudian mereduksi, menyajikan data yang telah terkumpul dan menarik kesimpulan. Data yang sudah terkumpul diuji dengan menggunakan triangulasi data. Baik triangulasi metode dengan membandingkan informasi atau data yang berbeda. Triangulasi antar-peneliti, dengan cara menggunakan lebih dari satu orang dalam mengumpulkan dan menganalisis data. Serta yang terakhir adalah triangulasi sumber data dengan menggunakan berbagai metode dan sumber perolehan data (Creswell dan Creswell 2017).

\section{Kondisi Perempuan Single Mother di Desa Ponteh}

Kondisi perempuan yang menjadi single mother di Desa Ponteh dari tahun ke tahun semakin meningkat. Dari 143 perempuan yang menjadi single mother, 96 perempuan disebabkan oleh kasus perceraian (Profil Desa, 2018). Kasus perceraian sendiri di Desa Ponteh disebabkan oleh kurang kesiapan psikologis saat membina keluarga akibat pernikahan usia anak, tidak adanya keharmonisan dalam keluarga, degradasi moral, tidak bertanggung jawab antar pasangan, masalah ekonomi, kecemburuan, poligami, serta gangguan dari pihak ketiga. Kasus perceraian ini banyak menimbulkan dampak negatif terutama bagi kaum perempuan. Mulai dari masalah ekonomi, karena sebagian besar keluarga yang bercerai di Desa Ponteh yang memiliki hak asuh anak di pengadilan dimenangkan perempuan. Selain masalah ekonomi, terdapat masalah emosional, membesarkan anak dan stigma oleh masyarakat sebagai perempuan yang gagal dalam menjaga rumah tangga. Stigma yang melekat lebih cenderung kepada kaum perempuan disorot oleh masyarakat daripada laki-laki, hal ini memang wajar karena dalam masyarakat Madura garis keturunan laki-laki yang menjadi acuan dalam segala hal (Wiyata 2006). Sehingga laki-laki selalu menjadi pusat (ordinat) dan perempuan menjadi subordinat daripada laki-laki, sehingga perempuan selalu dalam posisi yang dirugikan.

Bagi perempuan di Desa Ponteh yang menjadi single mother dan hidup dengan menanggung anak, memikul beban ganda dalam keluarga merupakan suatu keharusan. Perempuan yang menjadi single mother di Desa Ponteh sebagian besar bekerja sebagai buruh tani dan jasa menjaga warung makanan. Perempuan mencari nafkah untuk memenuhi kebutuhan hidup sendiri dan keluarga. Selain itu, perempuan saat selesai mencari nafkah tugas untuk mengasuh anak, membesarkan sampai mendidik juga dilakukan sendiri. Perempuan yang menjadi single mother mempunyai anak yang masih balita, saat bekerja dititipkan ke saudara dekat. Seperti yang dijelaskan Ibu Lia berikut:

“... kalau bekerja saya kan sebagai buruh tani. Anak saya yang masih berusia dua tahun kalau ditinggal sendiri di rumah kasihan. Saya juga harus bekerja untuk mencari nafkah. Mau tidak mau ya saya titipkan ke tetangga yang masih ada hubungan saudara. Supaya saat bekerja tidak kepikiran anak di rumah." (Ibu Lia 2019)

Penitipan anak yang dilakukan Ibu Lia supaya tidak mengganggu saat bekerja. Menurut Ibu Lia seorang perempuan yang menjadi single mother, peran ganda ini awalnya dirasa berat. Tetapi setelah mendapatkan dukungan dari keluarga dekat, teman kerja menjadi terbiasa dalam menjalani peran tersebut.

Hal yang memberatkan bagi perempuan yang menjadi single parent di Desa Ponteh adalah mengasuh atau membesarkan anak. Seperti yang dijelaskan Ibu Ika: 
“... kalau menurut saya, Dek ya, mengasuh anak ini, nanti kamu akan tahu sendiri ketika menjadi orang tua. Kalau sebatas mencari nafkah kan urusan ekonomi, tidak seberat mengasuh anak Dek. Karena mengasuh anak itu komplek, contohnya soal disiplin." (Ibu Ika 2019)

Mengasuh atau membesarkan anak harus memiliki keahlian khusus. Perempuan harus telaten, sabar, disiplin dan pintar saat mengasuh anak. Misal contoh, saat mengasuh anak diterapkan pola yang berhubungan dengan kedisiplinan yang dilakukan anak di luar rumah. Di tengah kesibukan dalam bekerja, Ibu Ika selalu melakukan pengecekan terhadap apa saja yang dilakukan anak di luar rumah, tentang pergaulan keseharian anak, bagaimana dia bermain, dengan siapa dia bermain.

Hal berbeda dijelaskan Ibu Rahma saat mengasuh atau membesarkan anak:

“... kalau saya saat bekerja anak tidak dalam pantauan Dek, yang jelas uang jajan saya berikan. Waktunya sekolah ya sekolah, saat ngaji ya ngaji seperti itu." (Ibu Rahma 2019)

Ibu Rahma menerapkan cara yang berbeda dengan Ibu Lia dalam mengasuh anak. Ibu Lia cenderung disiplin, sedangkan Ibu Rahma memberikan kebebasan anak untuk melakukan kegiatan di luar rumah dengan sedikit memantau. Hal ini wajar dilakukan Ibu Rahma dalam keseharian, sebab beliau bekerja sebagai penjaga warung makanan. Waktu untuk anak saat-saat tertentu saja. akibatnya kondisi anak sering tidak terkontrol saat sudah masuk jam kerja.

\section{Faktor-faktor Perempuan Menjadi Single Mother di Desa Ponteh}

Dari hasil observasi, terdapat fenomena perempuan lebih lama untuk kembali mencari pendamping hidup setelah ditinggal oleh pasangan baik cerai atau meninggal dunia. Bahkan, ada sebagian perempuan yang memilih untuk menjadi single mother dalam menjalankan institusi keluarga. Terdapat beberapa pendapat dari informan tentang kondisi perempuan di Desa Ponteh yang memilih menjadi single mother.

“... anak saya kan perempuan Dek, saya ingin memberi contoh agar mandiri. Perempuan mampu. Jadi untuk saat ini saya fokus membesarkan anak dulu Dek, sehingga kasih sayang dan perhatian saya berikan semua terhadap anak saya." (Ibu Lia 2019)

“... kalau saya masih tidak berfikir untuk berkeluarga Dek, fokus saat ini adalah membesarkan anak. Dulu sempat ingin menikah lagi, tapi Karena anak saya adalah yang utama untuk saat ini. Meskipun sendiri tanpa suami harus pinter membagi waktu, karena selain mengurus anak juga mencari nafkah." (Ibu Rahma 2019)

Alasan perempuan di Desa Ponteh menjadi single mother; Pertama, perempuan ingin membesarkan anak sendiri. Perempuan memilih untuk tidak menikah setelah bercerai, menurut ibu-ibu single mother demi kebaikan anak. Anak Ibu Lia adalah perempuan, sehingga membersarkan anak merupakan prioritas utama saat ini. Interaksi yang terjadi dalam keseharian memberikan contoh bagi anak, bagaimana perempuan itu menjadi mandiri. Harapan ibu-ibu single mother nanti, anak perempuannya dapat tumbuh dan berkembang menjadi anak yang mandiri dan tidak tergantung kepada orang lain. Kegigihan Ibu Rahma dapat terlihat saat membagi waktu antara peran mencari nafkah dan peran domestik dalam mengurus anak. Harapan agar anaknya mampu menempuh sampai pendidikan tinggi, sehingga mendorong Ibu Rahma untuk bekerja lebih keras dalam mencari nafkah. Bagi Ibu Rahma dulu sempat ada rencana untuk mencari pendamping 
lagi pasca bercerai. Tapi keputusan untuk menjadi single mother menjadi komitmen saat ini. Meskipun terdapat berbagai tantangan dalam kehidupan keseharian, mulai dari kondisi kejiwaan, kondisi perekonomian keluarga hingga persepsi masyarakat. Bagi Ibu Rahma, untuk saat ini prioritas adalah membesarkan anak demi kebaikan anak kedepannya. Komitmen menjadi single mother bagi Ibu Rahma adalah tidak peduli seburuk apapun tanggapan masyarakat, yang pasti membesarkan anak dan mendapatkan masa depan yang lebih baik dari saat ini adalah tujuan utama.

Kedua, bagi perempuan yang bercerai masih trauma, ketika hendak ingin menikah lagi takut mendapatkan pasangan yang sama dengan suami sebelumnya.

“... anak saya kan perempuan Dek, saya ingin memberi contoh agar mandiri. Perempuan mampu. Jadi untuk saat ini saya fokus membesarkan anak dulu Dek, sehingga kasih sayang dan perhatian saya berikan semua terhadap anak saya." (Ibu Munami 2019)

“... kalau saya masih tidak berfikir untuk berkeluarga Dek, fokus saat ini adalah membesarkan anak. Dulu sempat ingin menikah lagi, tapi Karena anak saya adalah yang utama untuk saat ini. Meskipun sendiri tanpa suami harus pinter membagi waktu, karena selain mengurus anak juga mencari nafkah." (Ibu Lia 2019)

Faktor traumatik menurut perempuan yang menjadi single mother memberikan pengaruh yang melemahkan ketika menjalani kehidupan tanpa pendamping. Sehingga perempuan menjadi single mother bagi perempuan lebih memberikan ketenangan daripada kembali mencari pendamping.

Ketiga, pemahaman ajaran agama Islam. Dalam Islam dijelaskan jika perempuan saat di akhirat akan bersama dengan suami yang terakhir (surga). Seperti yang dijelaskan oleh Ibu Ika, mantan istri kiai di Desa Ponteh.

“... setelah ditinggal suami saya memang tidak ada rencana untuk menikah kembali Dek, karena saya yakin yang akan membawa saya ke surga kelak adalah almarhum suami." (Ibu Ika 2019)

Menurut beliau, tidak lagi membina keluarga setelah ditinggal suami karena takut kelak di akhirat tidak dapat berjumpa dengan mantan suami. bagi Ibu Ika, yang dianggap bisa menyelamatkan beliau ketika di akhirat nanti adalah mantan suami semasa hidup di dunia. Pehaman ini tetap dipegang teguh sampai sekarang, meskipun sudah lebih 30 tahun menjadi single mother. Ibu Ika menjelaskan jika dulu saat masih muda setelah ditinggal suami meninggal dunia sempat dilamar oleh beberapa laki-laki untuk dijadikan istri. Tapi semua ditolak karena tetap berpegang teguh pada pemahaman ajaran agama ini.

Keempat, gengsi, perempuan ingin membuktikan meskipun sendiri mampu mengelola rumah tangga dan membesarkan anak sendiri dengan baik. Gengsi terutama ditujukan untuk mantan suami. seperti yang dijelaskan ibu Munami,

“... saya ingin menunjukkan kalau saya bisa membesarkan anak tanpa suami, karena mantan suami menikah lagi dengan perempuan yang masih satu kampong. Jadi masih sering dibicarakan dalam masyarakat." (Ibu Munami 2019)

Hidup sebagai single mother dan mengurus anak tanpa campur tangan suami atau pasangan yang baru, dapat membuktikan jika perempuan menunjukkan eksistensi dalam hal membesarkan anak. Perempuan dapat dilihat sebagai sosok yang independent dan bisa bertahan hidup meskipun tanpa adanya pendamping. Ibu Munami lebih 
baik hidup sendiri dengan bekerja keras untuk mencari nafkah dan membesarkan anak daripada hidup dalam tekanan batin saat ada pasangan.

Setelah bercerai, perempuan di desa Ponteh sebagian besar lebih memilih hidup sendiri untuk menjadi single mother dalam keluarga. Berbeda dengan laki-laki yang cenderung lebih cepat menikah lagi setelah bercerai. Pilihan hidup yang dilakukan oleh perempuan jika dihubungkan dengan rasionalitas Weber, tindakan rasional perempuan yang memilih menjadi single mother berhubungan dengan pertimbangan yang sadar akan pilihan tersebut, kemudian dinyatakan dalam tindakan (Ritzer dan Douglas 2011). Rasional di sini merupakan sesuatu yang masuk akal, dengan dibuktikan oleh tindakan-tindakan yang mendukung dari pilihan rasional tersebut.

Sedangkan jika dibandingkan dalam perspektif pilihan rasional Coleman, perempuan yang menjadi single mother merupakan tindakan berdasarkan tujuan tertentu, dan tujuan itu ditentukan oleh nilai-nilai atau preferensi (pilihan). Perempuan dipandang sebagai manusia yang mempunyai maksud dan tujuan tertentu ketika dia memilih untuk tidak membina keluarga lagi setelah ditinggal pasangan, baik cerai/meninggal dunia. Pilihan rasionalitas juga ditentukan oleh bagaimana perempuan dalam mencapai tujuan yang sudah ditentukan. Perempuan dipandang mempunya nilai atau pilihan, berbagai keperluan, kepentingan bahwa pilihan perempuan menjadi single mother tindakan yang dilakukan untuk mencapai tujuan yang sesuai dengan tingkatan pilihannya. Selanjutnya, menurut Coleman dalam tindakan sosial, selain aktor yaitu perempuan dalam menentukan pilihan rasional juga dipengaruhi oleh sumber daya. Perempuan me- miliki peran untuk melakukan tindakan, di mana tindakan tersebut diarahkan dan mempunyai tujuan yang sudah ditentukan. Sedangkan sumber daya merupakan sesuatu yang dianggap menarik oleh pihak lain, tetapi sumber daya tersebut dapat dikontrol oleh perempuan. Sehingga pilihan rasional perempuan menjadi single mother sesuai dengan tujuan dan mampu menjalankan fungsi dalam keluarga sesuai dengan sumber daya yang dimiliki (Upe 2010).

\section{Resiliensi Single Mother di Desa Ponteh}

Setelah perempuan di Desa Ponteh memutuskan untuk menjadi single mother, banyak tantangan baik dari individu, keluarga dan lingkungan masyarakat. Saat ditinggal cerai, dan memilih untuk tidak mencari pendamping hidup lagi, maka pekerjaan utama berubah. Awalnya menjadi ibu rumah tangga yaitu mengurus anak, suami, fungsi produksi kini harus mencari nafkah. Sehingga menjalani peran ganda bagi seorang single mother merupakan suatu keharusan. Dalam melihat peran ganda akan terlihat ketika perempuan yang menjadi single mother menjalaninya. Bagi sebagian perempuan, menjadi single mother menjadi suatu nilai lebih.

“... bagi saya sendiri, seorang ibu yang membesarkan sendiri seorang anak adalah suatu kebanggan. Bahwa saya itu mampu dan dapat berbuat sesuatu untuk masa depan anak." (Ibu Lia 2019)

Dalam kasus ini perempuan yang menjadi single mother dapat menunjukkan kepada masyarakat bahwa perempuan mampu untuk mengelola peran ganda dengan baik. Hal ini membuktikan bahwa perempuan yang menjadi single mother di Desa Ponteh memiliki peran besar dan penting terhadap kehidupan keluarga dan masya- 
rakat. Saat menjalani peran ganda, tentu seorang ibu akan mengalami kekurangan waktu untuk menjalankan peran seorang ibu. Ibu sebagai mendidik anak, mengurus keperluan dan kebutuhan anak, dan proses pembelajaran. Menurut Ibu Ika, salah seorang informan yang bekerja sebagai penjaga warung makan:

“... waktu untuk keluarga menjadi berkurang, karena saya berangkat kerja sekatar jam 6.30 WIB dan pulang sekitar sore, kadang saat pelanggan sedang ramai, bisa sampai setelah shalat Maghrib." (Ibu Ika 2019)

“... waktu untuk keluarga ya sekitar habis shalat Maghrib. Karena tuntunan saya harus mencari nafkah. Kadang saat pulang ke rumah anak sudah tidur Dek" (Ibu Rahma 2019)

“... Adek kan sudah tahu sendiri kalau buruh tani bekerjanya seperti apa, berangkat pagi pulang sore. Jadi waktu untuk keluarga sangat sedikit Dek." (Ibu Lia 2019)

Hal ini memang wajar, karena perempuan yang menjadi single mother fungsi utama berubah menjadi kepala keluarga, yaitu mencari nafkah. Kekurangan waktu dalam menjalankan peran sebagai ibu rumah tangga menjadi berkurang, karena sebagain besar waktu dihabiskan untuk bekerja di luar rumah yaitu mencari uang. Perempuan yang memilih menjadi single mother memiliki tantangan dan butuh perjuangan yang lebih dalam menjalani peran daripada perempuan yang hidup bersama seorang pendamping (suami). bagi seorang single mother, mengelola keluarga tanpa seorang pendamping bukan sesuatu yang menjadi kendala dan tetap pasrah pada keadaan.

Keberhasilan perempuan yang menjadi single mother di Desa Ponteh adalah semangat juang dan sikap optimisme dalam menjalani peran, baik sebagai individu, keluarga atau masyarakat.

“... dijalani saja Dek, memang awalnya berat, tapi saya kan tidak harus selalu dalam kondisi seperti ini. Lama-lama juga dapat menyesuaikan dengan masyarakat dan tempat kerja" (Ibu Munami 2019)

“... kadang masyarakat melihat sebelah mata, tapi pilihan ini adalah tanggung jawab sendiri. Jadi harus optimis Dek dalam menjalani kehidupan sebagai janda." (Ibu Lia 2019)

Karena menjalani hidup single mother awalnya bagi beberapa perempuan di Desa Ponteh merupakan suatu tekanan. Selain harus menanggung berbagai beban keluarga, misal; justifikasi masyarakat sebagai perempuan yang gagal dalam membina rumah tangga (jika bercerai), beban ekonomi, beban moral, beban sosial, pengasuhan anak, dan masalah biologis seputar seks. Modal utama dari perempuan yang menjadi single mother selain optimisme, perlu penyesuaian diri dari berbagai masalah yang dihadapi. Seperti yang dijelaskan Ibu Munami,

“... saya punya harapan anak saya nanti lebih baik dari saya. Ya setidaknya pendidikan da pekerjaan tidak seperti saya Dek." (Ibu Munami 2019)

Keinginan yang kuat untuk memberikan yang terbaik bagi anak-anaknya. Dengan harapan anak-anak yang ditanggung menjalani nasib yang lebih baik dari yang ditanggungnya saat ini. Optimisme ini memberikan dorongan, kekuatan baru, semangat baru bagi single mother bahwa beratnya beban yang dihadapi dalam hidup tidak akan mempengaruhi keyakinan mereka dalam mencukupi kebutuhan keluarga.

Ibu Munami yakin berbagai kesulitan, tantangan, cobaan sebagai single mother akan berubah 
menjadi lebih baik. Harapan ini selalu dilakukan dan diingat saat melakukan pekerjaan atau saat berkumpul dengan keluarga di rumah. Para perempuan yang menjadi single mother di Desa Ponteh merasa lebih kuat di tengah masyarakat. Hal ini perlu pembuktian bahwa meskipun tidak didukung lingkungan masyarakat, kehidupan akan terus berjalan dan semua membutuhkan biaya. Sedangkan Ibu Lia, menjelaskan resiliensi yaang dilakukan saat menjadi single mother adalah berjuang, bekerja keras dan berdoa lebih dekat kepada Allah. Bagi Ibu Lia, semua ketentuan ini adalah ujian yang diberikan Allah kepada dirinya dan keluarga. Untuk itu perlu mendekatkan diri kepada Allah dan berusaha sekuat tenaga untuk menjalani kehidupan dalam masyarakat. Ibu Lia percaya jika pemberian rezeki bukan dari suami, melainkan dari Allah dengan bekerja keras. Jika berusaha, maka Allah akan memberikan, jika bersykur maka nikmatnya akan ditambah.

Selain optimis, para perempuan yang menjadi single mother di desa Ponteh selalu berfikir positif, menganalisa permasalahan yang dihadapi untuk menemukan solusi yang terbaik. Berifikir positif dan tetap tenang meskipun hidup di bawah tekanan. Perempuan yang memiliki kemampuan mengelola emosi dengan baik mempermudah dalam menemukan solusi dari masalah yang dihadapi. Melakukan aspek positif, misal dengan mengikuti kegiatan-kegiatan acara khusus perempuan. Baik yang bersifat sosial atau kegiatan keagamaan. Misal di Desa Ponteh ada kegaiatan PKK, kompolan (pengajian agama khusus perempuan).

Konsep Max Weber dapat dijadikan sebagai pembanding untuk melihat resiliensi yang dilakukan perempuan single mother di desa
Ponteh. Konsep Weber tentang because motive dan in order to motive. Penjelasan dari because motive merupakan sebab perempuan melakukan resiliensi, di mana pada akhirnya perempuan mengalami perubahan dalam pola prilaku sosial, antara sebelum memutuskan menjadi single mother. Sedangkan maksud Weber tentang in order to motive merupakan sebuah tujuan yang menjadi sasaran agar tercapai keinginan yang dimaksud. Posisi because motive adalah motif perempuan dalam melakukan resiliensi, baik dalam lingkup diri, keluarga atau masyarakat untuk dapat bertahan dan melangsungkan siklus kehidupan (Ritzer dan Douglas 2011).

\section{Kesimpulan}

Terdapat beberapa faktor tentang fenomena perempuan menjadi single mother di Desa Ponteh Kecamatan Galis Kabupaten Pamekasan. Beberapa faktor yang mendasari perempuan di Desa Ponteh lebih lama untuk tidak membina keluarga setelah ditinggal suami baik yang meninggal dunia atau bercerai daripada laki-laki. Pertama, perempuan ingin membesarkan anak sendiri. kedua, bagi perempuan yang bercerai masih trauma, ketika hendak ingin menikah lagi takut mendapatkan pasangan yang sama dengan suami sebelumnya. ketiga, pemahaman ajaran agama Islam, dalam Islam dijelaskan jika perempuan saat di akhirat akan bersama dengan suami yang terakhir (surga). keempat, gengsi, perempuan ingin membuktikan meskipun sendiri mampu mengelola rumah tangga dan membesarkan anak sendiri dengan baik. Gengsi terutama ditujukan untuk mantan suami.

Resiliensi yang dilakukan perempuan yang menjadi single mother secara garis besar adalah 
dengan menjalankan peran ganda. Perempuan lebih aktif dalam kegiatan produktif, tetapi tidak melupakan peran domestik dalam rumah tangga. Perempuan bekerja lebih keras, bahkan pekerjaan berat yang lazim dilakukan laki-laki tetap dikerjakan. Artikel ini terbatas pada bahasan perempuan lebih lama untuk hidup sendiri dalam mengurus keluarga daripada laki-laki yang cepat menikah kembali ketika bercerai. Perlu penjelasan perbandingan dari pihak laki-laki untuk menjelaskan fenomena resiliensi dan single mother ini.]

\section{Daftar Pustaka}

Adela, Fernanda Putra, Zakaria Zakaria, Nurlela Nurlela, dan Adil Arifin. 2019. "Politik Gender dan Otonomi Daerah: Upaya Pemenuhan Hak Perempuan Nelayan di Desa Sei Nagalawan." JPPUMA: Jurnal Ilmu Pemerintahan dan Sosial Politik Universitas Medan Area 7(1):19-29.

Arini, Ni Wayan. 2014. "Kepemimpinan Lokal dan Kehidupan Sosial Politik Perempuan di Dua Desa Bali Aga Kabupaten Buleleng." Jurnal Ilmu Sosial dan Humaniora 3(2): 410-21.

Bianca, Rhapsodea. 2014. "Konstruksi Sosial Single Mother di Kota Surabaya (Studi Deskriptif tentang Single Mother Berusia Produktif yang Mempertahankan Statusnya sebagai Orang Tua Tunggal)." Universitas Airlangga, Surabaya.

Cairney, John, Michael Boyle, David R. Offord, dan Yvonne Racine. 2003. "Stress, Social Support and Depression in Single and Married Mothers." Social Psychiatry and Psychiatric Epidemiology 38(8):442-49.
Creswell, John W. dan J. David Creswell. 2017. Research Design Qualitative, Quantitative, and Mixed Methods Approaches. 3 ed. Singapura: SAGE Publications, inc.

Edin, Kathryn. 2000. "What Do Low-Income Single Mothers Say about Marriage?" Social Problems 47(1):112-33.

Hasanah, Uswatun dan Sofia Retnowati. 2019. "Dinamika Resiliensi Ibu Single Parent dengan Anak Tuna Ganda." Gadjah Mada Journal of Psychology (GamajoP) 3(3):15161.

Hidayati, Nurul. 2015. "Beban Ganda Perempuan Bekerja (Antara Domestik dan Publik)." Muwazah 7(2):108-19.

Hude, Darwis. 2001. Menjadi Single Parent bukan Sebuah Pilihan. Jakarta: Grafindo Persada.

Layliyah, Zahrotul. 2013. "Perjuangan Hidup Single Parent." Jurnal Sosiiologi Islam 3(1): 88-102.

Matondang, Armansyah. 2014. "Faktor-faktor yang Mengakibatkan Perceraian dalam Perkawinan." JPPUMA: Jurnal Ilmu Pemerintahan dan Sosial Politik UMA 2(2): 141-50.

Mawardi, Kholid, Siti Ma'sumah, dan Faradiena Zulizar. 2017. "Strategi Pemenuhan Kebutuhan Ekonomi Janda Cerai Mati (Studi Kasus Janda Cerai Mati di Desa Sikanco Kecamatan Nusawungu Kabupaten Cilacap)." Jurnal Penelitian Agama 18(2):224-40.

Miftahurrohmah, Miftahurrohmah. 2015. "Manajemen Keluarga Perempuan Single Parent: Telaah Gender Kehidupan Keluarga Tenaga Kerja Indonesia." Palastren: Jurnal Studi Gender 8(1):125-144.

Miles, M. B., A. M. Huberman, dan J. Saldana. 2014. Qualitative Data Analysis. California: SAGE Publications. 
Nurpuspita, Dessi dan Yeniar Indriana. 2018. "Hardiness pada Single Mother (Interpretative Phenomenological Analysis pada Buruh Pabrik Bulu Mata di Kabupaten Purbalingga)." Empati 7(3):230-35.

Pandapotan, Sihar dan Trisni Andayani. 2018. "Mekanisme Survival Perempuan Pemecah Batu di Desa Marjanji, Kecamatan Sipispis Kabupaten Serdang Bedagai." JUPIIS: Jurnal Pendidikan Ilmu-ilmu Sosial 10(1):138-45.

Paramitha, Ida Ayu Pradnya dan Luh Kadek Pande Ary Susilawati. 2016. "Resiliensi Perempuan Janda Nyerod yang pernah Mulih Deha." Jurnal Psikologi Udayana (Edisi Khusus):92-104.

Rahayu, Afina Septi. 2017. "Kehidupan Sosial Ekonomi Single Mother dalam Ranah Domestik dan Publik." Jurnal Anaslisa Sosiologi 6(1):82-99.

Ramadhani, Ayuuna Ulfa. 2015. "Feminisasi Kemiskinan pada Single Parent (Studi Analisis Gender Mekanisme Survival Perempuan Kepala Rumah Tangga Masyarakat Perantauan di Jagir Surabaya)." Paradigma: Jurnal Online Mahasiswa S1 Sosiologi UNESA3(3).
Ritzer, George dan Goodman J. Douglas. 2011. Teori Sosiologi Modern. Jakarta: Kencana Predana Media Group.

Saprin, Saprin. 2015. "Resiliensi Single Parent pada Keluarga Buruh Tani: Studi Kasus Single Parent karena Perceraian Ilegal di Desa Gelanggang, Kec. Sakra Timur, Kab. Lombok Timur NTB." UIN Sunan Kalijaga, Yogyakarta.

Solikhah, Amirotun. 2016. "Problematika dan Resiliensi keluarga Single Parent (Studi kasus Empat Keluarga di Desa Sabdodadi Bantul)." UIN Sunan Kalijaga, Yogyakarta.

Upe, Ambo. 2010. Tradisi Aliran dalam Sosiologi. Jakarta: Raja Grafindo.

Wahyuni, Sri, RB Soemanto, dan Bagus Haryono. 2015. "Kenakalan Pelajar dalam Keluarga Single Parent: Studi Kasus pada Pelajar dalam Keluarga Single Parent di Sekolah Menengah Atas Negeri 1 Girimanto, Wonogiri Tahun 2012/2012." Jurnal Analisa Sosiologi 4(2):1-9.

Wiyata, A. Latief. 2006. Carok Konflik Kekerasan dan Harga Diri Orang Madura. 2 ed. Yogyakarta: LKiS. 
This page intentionally left blank. 